\title{
PROGRAM DINAMIK UNTUK PENDISTRIBUSIAN KOMODITI KERUPUK ‘9 BERLIAN’ WATES
}

\author{
Siti Maslihah \\ UIN Walisongo Semarang \\ Email : sitimaslihah@walisongo.ac.id
}

\begin{abstract}
Distribution is one aspect of marketing. Distribution is an activity that bridges between producers and consumers. If the product fails in distribution then the consumer has the opportunity to switch to another similarproduct. Profits earned by a manufacturer is influenced by several factors, one of which is the distribution. An area may not necessarily generate maximum profits if distribution power is propagated in the region. Profit analysis based on the distribution of distributor power needs to be done appropriately, such an analysis technique is called a dynamic program.

The purpose of this study is to determine the number of salespeople from small business '9 Berlian' crackers in Wates, amounting to 9 people distributor / sales. Its operational area is Semarang with details of the Boja-Cups, Ngaliyan-Mangkang, Central Semarang and East Semarang. The result of research based on the average selling of crackers 9 Berlian during the last three months shows the exact distribution that is in the Cangkiran-Boja region as many as 5 sales people, Ngaliyan-Mangkang area as much as none, Central Semarang area as many as 4 sales and East Semarang no. There is a $7.26 \%$ difference in the benefit of using a dynamic program of sales placements as

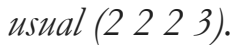

Keywords: Optimation, distribution, dynamic programme, crackers 9 Berlian

\begin{abstract}
Abstrak
Tujuan dari penelitian ini adalah untuk menentukan banyaknya tenaga penjual dari usaha kecil kerupuk ' 9 Berlian' di Wates yang berjumlah 9 orang distributor/ sales. Wilayah operasinya yaitu Semarang dengan rincian Cangkiran-Boja, Ngaliyan-Mangkang, Semarang Tengah dan Semarang Timur. Hasil penelitian berdasarkan rata-rata penjualan kerupuk 9 Berlian selama tiga bulan terakhir menunjukkan pendistribusian yang tepat yaitu di wilayah Cangkiran-Boja sebanyak 5 orang sales, wilayah NgaliyanMangkang tidak ada, wilayah Semarang Tengah sebanyak 4 orang sales dan wilayah Semarang Timur tidak ada. Terdapat selisih keuntungan sebesar Siti Maslihah, Aplikasi Program Dinamik..


$7.26 \%$ lebih baik menggunakan program dinamik dari penempatan sales

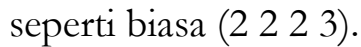

Keywords: Optimasi, distribusi, program dinamik. kerupuk '9 Berlian’

\section{PENDAHULUAN}

Distribusi merupakan salah satu aspek dari pemasaran. Distribusi juga dapat diartikan sebagai kegiatan pemasaran yang berusaha memperlancar dan mempermudah penyampaian barang dan jasa dari produsen kepada konsumen sehingga penggunaannya sesuai dengan yang diperlukan (jenis, jumlah, harga, tempat dan saat yang diperlukan). Jadi dapat dikatakan bahwa distribusi merupakan kegiatan yang menjembatani antara produsen dengan konsumen. Pelaku kegiatan distribusi dinamakan distributor. Kegiatan distribusi memegang peranan penting dalam penjualan dari produsen ke konsumen. Kesetiaan seorang konsumen tidak hanya dipengaruhi oleh kualitas suatu produk dan kebutuhan akan suatu produk tersebut akan tetapi juga dipengaruhi oleh kemudahan yang diperoleh konsumen untuk mendapatkan produk tersebut. Jika produk tersebut gagal dalam pendistribusian maka konsumen berpeluang untuk beralih ke produk lain yang sejenis.

Salah satu yang sangat mendasar dalam distribusi adalah masalah transportasi/ pengangkutan. Kegiatan ini menjadi penting karena mengingat jarak yang cukup jauh antara tempat produsen dengan tempattempat konsumen. Seorang distributor tentunya ingin mendapatkan keuntungan yang sebesar-besarnya dari komoditi yang diambilnya dari produsen untuk dikirim kepada konsumen dalam sekali kirim barang. Distributor yang semacam ini adalah distributor lepas, di mana mereka tidak dibayar dan tidak mempunyai perjanjian kerjasama dengan pihak produsen akan tetapi mereka merupakan badan lepas yang membeli barang dari 
produsen untuk dijual kembali kepada konsumen sehingga mereka mengharapkan keuntungan yang sebesar-besarnya dari kegiatan distribusi yang mereka lakukan.

Penempatan banyaknya sales di suatu wilayah tertentu memegang peranan yang penting dalam pencapaian keuntungan. Besarnya keuntungan yang didapatkan oleh seorang produsen kerupuk tidak selalu sebanding dengan banyaknya sales yang dipunyai, jika suatu wilayah terlalu banyak pesaingnya maka bukan solusi yang tepat jika terlalu banyak menempatkan tenaga sales di wilayah tersebut. Banyak faktor yang mempengaruhi suatu produk disukai konsumen. Demikian juga banyak faktor yang mempengaruhi besarnya keuntungan seorang produsen.

Seorang sales kerupuk akan membawa beberapa karung kerupuk yang sudah dibungkus kecil-kecil atau yang belum dibungkus dan siap makan untuk disetorkan kepada warung-warung atau pedagang di pasar. Harga jual kerupuk yang disetorkan ke warung dengan harga jual kerupuk yang dijual ke pedagang di beberapa pasar tentunya berbeda, di mana harga jual di warung lebih tinggi dibandingkan harga jual di beberapa pasar. Dengan berbagai pertimbangan tidak mungkin sales kerupuk tersebut menyetorkan semua kerupuknya ke pedagang kecil seperti warung-warung meskipun harganya lebih tinggi dibanding harga di pasar. Selama ini sales kerupuk "9 Berlian" dalam distribusinya ke warung-warung kecil dan pasar tidak berdasarkan analisis keuntungan yang didapat pada periode sebelumnya. Pada penelitian ini akan membahas bagaimana strategi yang tepat untuk mendistribusikan kerupuk agar diperoleh hasil yang maksimal dengan sedikit kerugian ditinjau dari ilmu matematika. Metode yang digunakan untuk mengoptimalkan keuntungan dalam distribusi kerupuk "9 Berlian" adalah menggunakan program dinamik. Program dinamik ini merupakan suatu teknik matematik untuk menentukan serangkaian keputusan yang 
saling terkait, serta memberikan suatu prosedur yang sistematik untuk menentukan kombinasi optimal dari keputusan yang hendak ditentukan itu.

\section{RUMUSAN MASALAH}

Berdasarkan latar belakang di atas maka yang menjadi permasalahan penelitian ini adalah:

1. Bagaimanakah membuat model matematika untuk masalah memaksimumkan keuntungan pada pendistribusian sales kerupuk 9 Berlian Wates

2. Bagaimanakah proporsi penempatan sales yang tepat agar didapatkan keuntungan yang maksimal

\section{KAJIAN PUSTAKA}

\section{Riset Operasi}

Riset operasi berasal dari Inggris yang merupakan suatu hasil studi operasi-operasi militer selama Perang Dunia II. Istilah riset oerasi pertama kali digunakan pada tahun 1940 oleh Mc Closky dan Trefthen di suatu kota kecil Bowdsey Inggris. Kata operasi dapat didefinisikan sebagai tindakantindakan yang diterapkan pada beberapa masalah atau hipotesa, sementara riset dapat didefinisikan sebagai suatu proses yang terorganisasi dalam mencari kebenaran akan masalah atau hipotesa.

\section{Definisi 1}

Riset operasi adalah penerapan metode-metode ilmiah terhadap masalah-msalah rumit yang muncul dalam pengarahan dan pengelolaan dari suatu sistem besar manusia, mesin, bahan dan uang dalam industri, bisnis, pemerintahan dan pertahanan (Operational Research Society of Great Britain) 


\section{Definisi 2}

Riset operasi berkaitan dengan menentukan pilihan secara ilmiah bagaimana merancang dan menjalankan sistem manusia-mesin secara terbaik, biasanya membutuhkan alokasi sumber daya yang langka (Operation Research Society of America)

\section{Definisi 3}

Riset operasi adalah seni memberikan jawaban buruk terhadap masalah-masalah, yang jika tidak, memiliki jawaban yang lebih buruk. (T.L Saaty)

\section{Definisi 4}

Riset operasi adalah pendekatan dalam pengambilan keputusan yang ditandai dengan penggunaan pengetahuan ilmiah melalui usaha kelompok antar disiplin yang bertujuan menentukan penggunaan terbaik sumber daya yang terbatas. (Hamdi A. Taha, 1976).

\section{Definisi 5}

Riset operasi dalam arti luas dapat diartikan sebagai penerapan metodemetode, teknik-teknik, dan alat-alat terhadap masalah-masalah yang menyangkut operasi-operasi dari sistem-sistem, sedemikian rupa sehingga memberikan penyelesaian optimal. (Churchman, Ackoff, dan Arnoff, 1957).

Riset operasi berusaha menetapkan arah tindakan terbaik (optimum) dari sebuah masalah keputusan dibawah pembatasan sumber daya yang terbatas. Istilah riset operasi sering kali diasosiasikan secara eksklusif dengan penggunaan teknik-teknik matematis model matematis merupakan inti dari riset operasi, pemecahan masalah tidaklah hanya sekedar pengembangan dan pemecahan model-model matematis. Secara spesifik, masalah keputusan biasanya mencakup faktor-faktor penting yang tidak berwujud dan tidak dapat diterjemahkan secara langsung dalam bentuk model matematis. 
Sebuah ilustrasi yang baik dari kasus diatas adalah salah satu versi dari masalah elevator yang dikenal luas. Sebagai tanggapan terhadap keluhan para penghuni tentang lambatnya elevator disebuah bangunan perkantoran yang besar, sebuah pemecahan yang didasari oleh analisis teori jalur antrian ditemukan tidak memuaskan. Setelah mempelajari sistem tersebut lebih lanjut, ditemukan bahwa keluhan para penghuni tersebut lebih disebabkan oleh kebosanan, karena pada kenyataannya, waktu menunggu sangat singkat. Sebuah pemecahan diajukan dimana sebuah cermin panjang dipasang ditempat masuk elevator. Keluhan menghilang karena para pengguna elevator asik memandangi diri mereka sendiri dan orang lain sambil menunggu elevator.

Ilustrasi elevator ini menggarisbawahi pentingnya memandang aspek matematis dari riset operasi dalam konteks yang lebih luas dari sebuah proses pengambilan keputusan yang unsur-unsurnya tidak dapat diwakili sepenuhnya oleh sebuah model matematis. Sebagai sebuah teknik pemecahan masalah, riset operasi harus dipandang sebagai ilmu dan seni. Aspek ilmu terletak dalam penyediaan teknik-teknik matematis dan algoritma untuk memecahkan masalah keputusan yang tepat. Riset operasi adalah sebuah seni karena keberhasilan dalam semua tahap yang mendahului dan melanjuti pemecahan dari sebuah model matematis sebagian besar bergantung pada kreativitras dan kemampuan pribadi dari mereka yang menganalisis pengambilan keputusan.

\section{Program Dinamik}

Pada dasarnya medel-model penelitian operasional bertujuan mencari solusi pemecahan masalah yang optimal dari nilai-nilai variabel keputusan. Variabel keputusan merupakan variabel yang dapat dirubah dan dikendalikan oleh pengambil keputusan. Dalam kenyataannya kehidupan berbagai jenis masalah dapat diformulasikan ke dalam berbagai jenis model. Salah satu masalah yang dapat dipecahkan secara bertahap dengan membagi 
masalah menjadi bagian-bagian yang lebih kecil (dekomposisi) dan pada solusi dapat terjawab pada tahap akhir dengan menyatukan keputusankeputusan pada tahap-tahap sebelumnya yang ada. Teknik pemecahan masalah yang sistematis untuk memperoleh jawaban dari masalah multistage problem solving disebut Program Dinamis

Program dinamik adalah suatu teknik matematis yang biasanya digunakan untuk membuat suatu keputusan dari serangkaian keputusan yang saling berkaitan. Pemrograman dinamik ini pertama kali dikembangkan oleh seorang ilmuwan bernama Ricard Bellman pada tahun 1957. Dalam hal ini program dinamik menyediakan prosedur sistematis untuk menentukan kombinasi keputusan yang optimal. Tujuan utama model ini adalah untuk mempermudah penyelesaian persoalan optimasi yang mempunyai karakteristik tertentu. Masalah optimasi dapat diselesaikan dengan program linier dan program dinamik. Perbedaan antara program dinamik dengan program linier adalah pada program dinamik tidak terdapat rumusan matematika secara baku dan tipe penyelesaian masalah yang didekati secara umum.

Karakteristik Dari Masalah-Masalah Pada Program Dinamik:

1. Masalah tersebut dapat dibagi ke dalam tahapan-tahapan, serta membutuhkan sebuah keputusan kebijakan (policy decision) pada tiap tahapan.

2. Tiap tahapan memiliki sejumlah stage yang bersesuaian dengannya. Secara umum, stage memiliki berbagai macam kemungkinan kondisi tergantung pada sistem yang ada pada tahapan masalah tersebut. Jumlah dari stage mungkin terbatas mungkin pula tak terbatas.

3. Efek dari kebijakan keputusan yang diambil pada tiap tahapan adalah untuk mentransformasikan stage pada saat itu ke stage yang bersesuaian 
pada tahapan berikutnya (dimungkinkan juga sebuah distribusi probabilitas).

4. Prosedur penyelesaian dirancang untuk mendapatkan kebijakan optimal untuk seluruh permasalahan, yaitu suatu perumusan dari keputusan kebijakan optimal pada tiap tahapan untuk tiap stage yang mungkin.

5. Diberikan stage saat ini, kebijakan optimal untuk tahapan yang tersisa independen terhadap kebijakan yang diambil pada tahapan-tahapan sebelumnya.

6. Prosedur penyelesaian diambil dengan mendapatkan kebijkan optimal pada tahapan terakhir.

7. Tersedia suatu relasi rekursif yang mengidentifikasikan kebijakan optimal untuk tahapan ke-n, jika diberikan kebijakan optimal pada tahapan ke-n+1

8. Jika relasi rekursif ini digunakan, prosedur penyelesaian berpindah mundur tahapan demi tahapan. Tiap kali mendapatkan kebijakan optimal untuk tahapan tersebut hingga didapat kebijakan optimal yang diawali pada tahapan mula-mula.

Penelitian ini dilakukan dengan melakukan wawancara dengan pemilik kerupuk "9 Berlian” yaitu Bp. Herman. Data yang didapatkan berupa hasil penjualan kerupuk selama 3 bulan terakhir. Berdasarkan data tersebut dilakukan analisis distribusi dengan menggunakan metode program dinamik.

\section{Langkah-langkah pemecahan masalah program dinamik:}

a. Tentukan prosedur pemecahan (maju atau mundur)

b. Tentukan tahap (stages)

c. Definisikan variabel status (stage) pada tiap tahap

d. Definisikan variabel keputusan pada tiap tahap

e. Definisikan fungsi pengembalian pada tiap tahap 
f. Definisikan fungsi transisi

g. Definisikan fungsi rekursif

h. Perhitungan

i. Tentukan solusi optimal dengan backtracking

\section{HASIL DAN PEMBAHASAN}

Industri rumah tangga kerupuk '9 Berlian' memiliki 9 orang karyawan yang selama ini ditempatkan di 4 wilayah sekitar wilayah Wates. Data ratarata keuntungan yang didapatkan berdasarkan hasil penjualan selama 3 bulan terakhir adalah sebagai berikut:

Tabel 1. keuntungan penjualan kerupuk

\begin{tabular}{|c|c|c|c|c|}
\hline Banya & Wilayah & & & \\
\hline $\begin{array}{l}\text { knya } \\
\text { tenaga } \\
\text { sales }\end{array}$ & $\begin{array}{l}\text { Wilayah- } \\
1\end{array}$ & $\begin{array}{l}\text { Wilayah- } \\
2\end{array}$ & $\begin{array}{l}\text { Wilayah- } \\
3\end{array}$ & $\begin{array}{l}\text { Wilayah- } \\
4\end{array}$ \\
\hline 1 & 155.400 & 130.400 & 136.800 & 136.400 \\
\hline 2 & 290.800 & 262.000 & 271.600 & 271.000 \\
\hline 3 & 406.600 & 391.200 & 407.400 & 406.400 \\
\hline 4 & 559.200 & 445.000 & 559.200 & 530.000 \\
\hline 5 & 761.000 & 550.000 & 686.200 & 667.200 \\
\hline 6 & 838.000 & 667.500 & 827.600 & 802.000 \\
\hline 7 & 945.000 & 780.000 & 952.400 & 937.600 \\
\hline 8 & 1.080 .600 & 886.500 & 1.085 .000 & 1.074 .200 \\
\hline 9 & 1.216 .800 & 1.020 .000 & 1.228 .800 & 1.209 .600 \\
\hline
\end{tabular}

Berdasarkan tabel 1 tersebut maka akan ditentukan kombinasi sales yang tepat sehingga didapatkan keuntungan yang maksimal. Prosedur pemecahan masalah mundur yang akan digunakan dalam kasus ini. 
Prosedur pemecahan masalah mundur diawali dari perhitungan keuntungan pada wilayah 4.

Secara matematis tujuan dari masalah dalam penelitian ini adalah:

Stage: wilayah $(1,2,3,4)$

Variabel keputusan: $x_{n}$ : Jumlah sales yang akan ditempatkan di wilayah $n$

$$
(n=1,2,3,4)
$$

Stage dari system: $s_{n}$ : jumlah sales yang masih tersedia untuk dialokasikan pada wilayah-wilayah distribusi.

Misal $p_{1}\left(x_{1}\right)$ menyatakan besarnya keuntungan dengan pengalokasian $x_{1}$ sales di wilayah $i$

Fungsi Objektif:

Maksimum

$\sum_{i=1}^{4} p_{i}\left(x_{i}\right)$ dengan $x_{i}$ non negative integer

Dengan kendala: $\sum_{i=1}^{4} x_{i}=9$ dengan $x_{i}$ : banyaknya sales di wilayah $i$

Dengan menggunakan struktur dasar program dinamik dibentuk $f_{n}\left(s_{n}, x_{n}\right)=p_{n}\left(x_{n}\right)+\max \left[\sum_{i=1}^{4} p_{i} x_{i}\right]$ dimana nilai maksimum diambil dari seluruh $x_{n+1}, \ldots x_{4}$

Sedemikian sehingga $\sum_{i=1}^{4} x_{i}=s_{n}, x_{i}$ nonnegative integer, $\mathrm{n}=1,2,3,4$ selanjutnya:

$f_{n}^{*}\left(s_{n}\right)=\max _{x_{n}=1, \ldots, s_{n}} f_{n}\left(s_{n}, x_{n}\right)$

$f_{n}\left(s_{n}, x_{n}\right)=p_{n}\left(x_{n}\right)+f_{n+1}^{*}\left(s_{n}-x_{n}\right)$ dengan $f_{5}^{*}=0$.berarti relasi rekursifnya adalah: 
$f_{n}^{*}\left(s_{n}\right)=\max _{x_{n}=1, \ldots, s_{n}}\left\{p_{n}\left(x_{n}\right)+f_{n+1}^{*}\left(s_{n}-x_{n}\right)\right\}, n=1,2,3,4$

1) Perhitungan pada stage 4 :

\begin{tabular}{|c|c|c|}
\hline$s_{3}$ & $f_{3}^{*}\left(s_{3}\right)$ & $x_{3}^{*}$ \\
\hline 1 & 136.400 & 1 \\
\hline 2 & 271.000 & 2 \\
\hline 3 & 406.400 & 3 \\
\hline 4 & 530.000 & 4 \\
\hline 5 & 667.200 & 5 \\
\hline 6 & 802.000 & 6 \\
\hline 7 & 937.600 & 7 \\
\hline 8 & 1.074 .200 & 8 \\
\hline 9 & 1.209 .600 & 9 \\
\hline
\end{tabular}

2) Perhitungan pada stage 3

\begin{tabular}{|c|c|c|c|c|c|c|c|c|c|c|c|c|}
\hline \multirow{2}{*}{$\begin{array}{l}\mathrm{S} 3 \backslash \\
\text { X3 }\end{array}$} & & \multicolumn{9}{|c|}{$f_{3}\left(s_{3}, x_{3}\right)=p_{3}\left(x_{3}\right)+f_{4}^{*}\left(s_{3}-x_{3}\right)$} & \multirow{2}{*}{$f_{3}^{*}\left(s_{3}\right)$} & \multirow{2}{*}{$x_{3}^{*}$} \\
\hline & 0 & 1 & 2 & 3 & 4 & 5 & 6 & 7 & 8 & 9 & & \\
\hline 0 & 0 & - & - & - & - & - & - & - & - & - & 0 & 0 \\
\hline 1 & 1364 & 1368 & - & - & - & - & - & - & - & - & 1368 & 1 \\
\hline 2 & 2710 & 2732 & 2716 & - & - & - & - & - & - & - & 2732 & 1 \\
\hline 3 & 4064 & 4078 & 4080 & 4074 & - & - & - & - & - & - & 4080 & 2 \\
\hline 4 & 5300 & 5432 & 5426 & 5438 & 5592 & - & - & - & - & - & 5592 & 4 \\
\hline 5 & 6672 & 6668 & 6780 & 6784 & 6956 & 6862 & - & - & - & - & 6956 & 4 \\
\hline 6 & 8020 & 8040 & 8016 & 8138 & 8302 & 8226 & 8276 & - & - & - & 8302 & 4 \\
\hline 7 & 9376 & 9388 & 9388 & 9374 & 9656 & 9572 & 9640 & 9524 & - & - & 9656 & 4 \\
\hline 8 & 10742 & 10744 & 10736 & 10746 & 10892 & 10926 & 10986 & 10888 & 10850 & - & 10986 & 6 \\
\hline 9 & 12090 & 12110 & 12092 & 12094 & 10892 & 12162 & 12340 & 12234 & 12214 & 122887 & 12340 & 6 \\
\hline
\end{tabular}


3) Perhitungan pada stage 2

\begin{tabular}{|c|c|c|c|c|c|c|c|c|c|c|c|c|}
\hline \multirow{2}{*}{$\begin{array}{l}\mathrm{S} 2 \backslash \\
\mathrm{X} 2\end{array}$} & & \multicolumn{9}{|c|}{$f_{2}\left(s_{2}, x_{2}\right)=p_{2}\left(x_{2}\right)+f_{3}^{*}\left(s_{2}-x_{2}\right)$} & \multirow{2}{*}{$f_{2}^{*}\left(s_{2}\right)$} & \multirow{2}{*}{$x_{2}^{*}$} \\
\hline & 0 & 1 & 2 & 3 & 4 & 5 & 6 & 7 & 8 & 9 & & \\
\hline 0 & 0 & - & - & - & - & - & - & - & - & - & & \\
\hline 1 & 1368 & 1304 & - & - & - & - & - & - & - & - & 1368 & 0 \\
\hline 2 & 2732 & 2672 & 2620 & - & - & - & - & - & - & - & 2732 & 0 \\
\hline 3 & 4080 & 4036 & 3988 & 3912 & - & - & - & - & - & - & 4080 & 0 \\
\hline 4 & 5592 & 5384 & 5352 & 5280 & 4450 & - & - & - & - & - & 5592 & 0 \\
\hline 5 & 6956 & 6896 & 6700 & 6644 & 5818 & 5500 & - & - & - & - & 6956 & 0 \\
\hline 6 & 8302 & 8260 & 8212 & 7992 & 7182 & 6868 & 6675 & - & - & - & 8302 & 0 \\
\hline 7 & 9656 & 9606 & 9576 & 9504 & 8530 & 8232 & 8043 & 7800 & - & - & 9656 & 0 \\
\hline 8 & 10986 & 10960 & 10922 & 10868 & 10042 & 9580 & 9407 & 9168 & 8865 & - & 10986 & 0 \\
\hline 9 & 12340 & 12290 & 12276 & 12214 & 11406 & 11092 & 10755 & 10532 & 10233 & 10200 & 12340 & 0 \\
\hline
\end{tabular}

4) Perhitungan pada stage 1

\begin{tabular}{|l|l|l|l|l|l|l|l|l|l|l|l|l|}
\hline \multirow{2}{*}{$\begin{array}{l}\text { S1 } \\
\mathrm{X} 1\end{array}$} & \multicolumn{7}{|c|}{$f_{1}\left(s_{1}, x_{1}\right)=p_{1}\left(x_{1}\right)+f_{2}^{*}\left(s_{1}-x_{1}\right)$} & \multirow{2}{*}{$f_{2}^{*}\left(s_{2}\right)$} & $x_{2}^{*}$ \\
\cline { 2 - 15 } & 0 & 1 & 2 & 3 & 4 & 5 & 6 & 7 & 8 & 9 & & \\
\hline 0 & 0 & - & - & - & - & - & - & - & - & - & & \\
\hline 1 & 1368 & 1554 & - & - & - & - & - & - & - & - & 1554 & 1 \\
\hline 2 & 2732 & 2922 & 2908 & - & - & - & - & - & - & - & 2922 & 1 \\
\hline 3 & 4080 & 4286 & 4276 & 4066 & - & - & - & - & - & - & 4286 & 1 \\
\hline 4 & 5592 & 5634 & 5640 & 5434 & 5592 & & & - & - & - & 5640 & 2 \\
\hline 5 & 6956 & 7146 & 6988 & 6798 & 6960 & 7610 & & - & - & - & 7146 & 1 \\
\hline 6 & 8302 & 8510 & 8500 & 8146 & 8324 & 8978 & 8388 & - & - & - & 8978 & 6 \\
\hline 7 & 9656 & 9856 & 9864 & 9658 & 9672 & 10342 & 9756 & 9458 & - & - & 10342 & 5 \\
\hline 8 & 10986 & 11210 & 11210 & 11022 & 11184 & 11690 & 11120 & 10826 & 10806 & - & 11690 & 5 \\
\hline 9 & 12340 & 12540 & 12564 & 12368 & 12551 & 13202 & 12468 & 12190 & 12174 & 12168 & 13202 & 5 \\
\hline
\end{tabular}

Penyelesaian optimal:

$$
\begin{array}{ll}
x_{1}^{*}=5, & s_{2}=9-5=4 \\
x_{2}^{*}=0, & s_{3}=4-0=4 \\
x_{3}^{*}=4, & s_{4}=4-4=0
\end{array}
$$


$x_{4}^{*}=0, \quad$ dengan $f_{1}^{*}(s)=1.320 .200$

Berdasarkan perhitungan pada stage 1 maka produsen kerupuk akan mendapatkan keuntungan yang optimal dengan menempatkan 5 oang sales pada wilayah I. Secara hitungan mundur, bedasakan perhitungan pada tabel pehitungan stage 2 keuntungan produsen akan maksimal jika wilayah II tidak diberikan sales. Berdasarkan perhitungan stage 3 didapatkan masih terdapat 4 ornag sales untuk ditempatkan pada wilayah III dan IV dan keuntungan maksimal akan didapatkan produsen jika menempatkan 4 orang tersebut pada wilayah III.. Jadi tidak terdapat sales di wilayah II dan IV karena tidak akan menghasilkan keuntungan yang maksimal. Hasil analisis menunjukkan tidak ada keuntungan yang maksimal di wilayah II dan IV, hal ini didukung dengan kenyataan di lapangan bahwa di wilayah II dan IV sudah banyak persaingan penjualan kerupuk sehingga banyak kerupuk yang dikembalikan ke sales.

\section{KESIMPULAN}

Hasil akhir yang didapatkan dari pemecahan masalah secara rekursif dengan meggunakan program dinamik yaitu sebagai berikut:

\begin{tabular}{lllll}
\hline $\begin{array}{l}\text { Banyaknya } \\
\text { sales }\end{array}$ & Wilayah 1 & Wilayah 2 & Wilayah 3 & Wilayah 4 \\
\hline $\mathbf{1}$ & 1 & - & - & - \\
$\mathbf{2}$ & 1 & - & 1 & - \\
$\mathbf{3}$ & 1 & - & 1 & 1 \\
$\mathbf{4 a}$ & - & - & 4 & - \\
$\mathbf{4 b}$ & 4 & - & - & - \\
$\mathbf{5}$ & 5 & - & - & - \\
$\mathbf{6}$ & 5 & - & 1 & - \\
$\mathbf{7}$ & 5 & - & 1 & 1 \\
$\mathbf{8}$ & 5 & - & 2 & 1 \\
$\mathbf{9}$ & 5 & - & 4 & - \\
\hline
\end{tabular}


Berdasarkan tabel tersebut dapat disimpulkan bahwa dengan banyaknya karyawan home industry kerupuk 9 Berlian sebanyak 9 orang sales maka penempatan sales yang tepat sehingga dapat menghasilkan keuntungan yang besar jika 5 orang sales berada di wilayah I yaitu wilayah Cangkiran-Boja dan 4 orang sales berada di wilayah III (Semarang Tengah). Selisih pendapatan yang didapatkan jika penempatan sales menggunakan analisis program dinamik dan tidak menggunakan analisis apapun adalah $7.26 \%$ lebih baik jika menggunakan analisis program dinamik.

\section{Referensi}

Eiselt, H.A., C-L Sanblom. 2007. Linear Programming and its Applications. Berlin: Springer.

Hotniar Siringoringo. 2005. Seri Teknik Riset Operasional. Yogyakarta: Graha Ilmu.

Sri Mulyono. 2017. Riset Operasi. Mitra Wacana Media.

Taha HA. 1996. Riset Operasi. Jakarta: Binarupa Aksara.

Roland Ganda Simanjuntak. Aplikasi Program Dinamik Untuk Mengoptimalkan Biaya Total Pada pengendalian produksi Minyak Sawit dan inti Sawit (studi kasus: PTPN IV (Persero) PKS Sawit Langkat) di muat dalam jurnal Saintia Matematika Vol 1 No 5 (2013), pp. 419-433. 